\title{
Main concepts of innovative technology in teaching language
}

\author{
Babamuradova L.X. ${ }^{1}$, Xikmatova D.A. ${ }^{2}$ \\ ${ }^{1,2}$ Bukhara State University, Uzbekistan
}

Email: babamuradova_1@umail.uz

\begin{abstract}
In article was written about innovative technologies, teaching technologies and the role of innovative technologies to teaching English. Here was explained the meaning of innovative technology in education.
\end{abstract}

Keywords: innovation, technology, innovative technology, ELL, teaching English, educational innovative technologies.

\section{INTRODUCTION}

Today's classrooms increasingly include students for whom English is a second language. Teaching English Language Learners through Technology explores the use of computers and technology as pedagogical tools to aid in the appropriate instruction of English language learners (ELLs) across all content areas. The authors identify various technologies and software programs regularly used in the classroom for all students that can also specifically aid ELLs. Teaching English Language Learners through Technology provides successful strategies for varying levels of accesswhether teachers have one computer in their classroom, have multiple computers, or can only occasionally use a computer lab. A fully annotated list of web and print resources completes the volume, making this a valuable reference to help teachers harness the power of computer-assisted technologies in meeting the challenges of including all learners in effective instruction.

Before starting to speak about innovative technologies in education we must answer to following questions:

What is education? What is technology? What is innovation? What is pedagogical technology? What is innovative technology? And when we need to these terms?

Let's start to answer for the first question: What is education?

L.V.Golish to his work "Projecting and planning of pedagogical technologies" said about education the following:

Education - the process and the result of the assimilation of human knowledge about the world, society itself, ways of thinking and activity, formation of self; cultural phenomenon that ensures its broadcast, reproducibility and shift; educational space - a set of institutions, public management and public associations that implement educational programs ${ }^{1}$.

Uzbek scientist, Methodist J.J. Jalolov said:

Education - mixture of bringing up with levels of theory of teaching, learning aims, methods, principles and processes ${ }^{2}$.

In Oxford dictionary we can see following meaning of education:

Education - the process of receiving or giving systematic instruction, especially at a school or university ${ }^{3}$.

In Collins Cobuild dictionary:

Education involves teaching people various subjects, usually at a school or college, or being taught.

In Macmillan Dictionary for advanced learners:

\footnotetext{
1 Л.В.Голиш,Д.М.Файзуллаев. Педагогик технологияларни лойихалаштириш ва режалаштириш. - Тошкент,2010й. $146 б$.

2 Jamol Jalolov. Foreign Language Teaching Methodology. - T., 2012, “O'qituvchi”.-415p.

${ }^{3}$ Oxford Dictionary of English, 3rd Edition. Oxford University Press 2010
} 
1. Education - the activity of educating people in schools, collages, and universities, and all the policies and arrangements concerning this.

2. Education - the process of providing people with information about an important issue.

According to these expressions we can say education is the process of educating and bringing up, giving some information (useful) to somebody, to teach somebody to some handicraft or occupation. The greatest Uzbek poet and writer Alisher Navoi said:

Haq yo'lida kim senga bir harf o'rgatmish ranj ila,

Aylamak oson emas oning haqqin ming ganj ila.

Translation:

Who taught you one letter in to the way of truth with difficulties,

You can't pay his/her this work with hundred benefits.

Here a great poet and writer emphasized teaching one letter to the way of truth is a great education (job). Education is very difficult and important for our youth, for our future.

Our second question which we must answer is: What is technology?

L.V.Golish wrote:

The term "technology" - from Greek means "techne"- skill, ability, art, and "logos"- word, study or learning ${ }^{4}$.

The term "technology" borrowed from industrial branch to pedagogy, and in this point of view it changes "from high psychological bases into pedagogical engineering area."5

"For pedagogy technology is another term, it doesn't look like anything, it has not any reason to find technique repetition ideas." ${ }^{\circ}$ - said A.M.Kushnir about technology.

J.J.Jalolov in his works said:

Technology - (from Greek "techne"- skill, "logos"-study or learning) methods and ways of leading some processes ${ }^{7}$.

The technologies of particular interest are those that are referred to as "conversational technologies," which allow for the creation and sharing of information (KPMG, 2003; Wagner, 2004). Another term of tensed to describe these technologies is the concept of "constructivist learning tools," which encourage, and are focused on, users creating, or constructing, their own content (Seitzinger, 2006).

In Oxford dictionary:

Technology - 1) the application of scientific knowledge for practical purposes, especially in industry;

2) machinery and equipment developed from scientific knowledge;

3) the branch of knowledge dealing with engineering or applied sciences.

In Collins Cobuild dictionary we can see another expression to this term:

Technology refers to methods, systems, and devices which are the result of scientific knowledge being used for practical purposes.

Technology is differ from technique. Technique is a skill or ability in a particular field. J.Jalolov said : Technique came from Greek "techne". It means ability to do something.

From the pedagogical and methodological point of view we can say technology is a complex unit of abilities for teaching or teaching abilities. From the technical point of view it is the complex of techniques as computer technologies (complex unit of computer and their types).

And our third question for understanding innovative educational technologies is What is innovation?

From English innovation means something new, giving some new information. ${ }^{8}$

Innovation (lat. Innovatio - update, change) - emotionally evaluative attitude towards innovation, as opposed to the susceptibility of the subjects of innovation, new ideas and experiences. ${ }^{9}$ We always use innovation in our life. Every day we open some new thing in our life. Learning foreign language

\footnotetext{
4 Л.В.Голиш,Д.М.Файзуллаев. Педагогик технологияларни лойихалаштириш ва режалаштириш. - Тошкент,2010й. $146 б$.

5 Кушнир А.М. Методический плюрализм.//Школьные технологии.-2004.№4.-С.3-4.

${ }^{6}$ Кушнир А.М. Методический плюрализм.//Школьные технологии.-2004.№4.-С.3-4.

${ }^{7}$ Jamol Jalolov. Foreign Language Teaching Methodology. - T., 2012, "O'qituvchi”.-415p.

${ }^{8}$ Ishmuhammedov R., Abduqodirov A., Pardaev A. Ta'limda innovatsion texnologiyalar. - Toshkent, 2008.-181b.

9 Л.В.Голиш,Д.М.Файзуллаев. Педагогик технологияларни лойихалаштириш ва режалаштириш. -

Тошкент,2010й. 1466.
} 
can be the innovation, if it's new notion for him or her. Learning foreign languages is impossible to imagine without the use of multimedia learning tools. Of course, important tasks for the methodology of teaching foreign languages include providing opportunities to illustrate the actual process of communication in English, and creating an educational environment that provides real conditions for learning use of the target language and its culture. Innovative technologies help us to teach English more effective.

In Oxford dictionary we can find following meaning of Innovation:

1) An innovation is a new thing or a new method of doing something. For example, They produced the first vegetarian bean burger - an innovation which was rapidly exported to Britain.

2) the action or process of innovating

3) [count noun] a new method, idea, product, etc. Example, technological innovations designed to save energy

4) Innovation is the introduction of new ideas, methods, or things. Example, We must promote originality, inspire creativity and encourage innovation.

\section{CONCLUSION}

Totally, we can say innovation is new ideas, new methods, or things. It is the usage of something new.

And the next question What is pedagogical technology? And what is educational technology?

Pedagogical technology is notion or concept using at the process structuring of education and pedagogical events.10 This term firstly used in 1610 by Czech scientist Ian Amos Kaminski. He said all educational acts must show some results. In all educational projects must be put one or two or more aims and this technologies must help to do it correctly. This resulting process he called "Didactic machine".

\section{REFERENCES}

1. Л.В.Голиш,Д.М.Файзуллаев. Педагогик технологияларни лойихалаштириш ва режалаштириш. - Тошкент,2010й. 146б.

2. Jamol Jalolov. Foreign Language Teaching Methodology. - T., 2012, “O’qituvchi”.-415p.

3. Oxford Dictionary of English, 3rd Edition . Oxford University Press 2010

4. Кушнир А.М. Методический плюрализм.//Школьные технологии.-2004.№4.-С.3-4.

5. Ishmuhammedov R., Abduqodirov A., Pardaev A. Ta'limda innovatsion texnologiyalar. Toshkent, 2008.-181b.

\footnotetext{
10 Л.В.Голиш,Д.М.Файзуллаев. Педагогик технологияларни лойихалаштириш ва режалаштириш. Тошкент,2010й. 146б.
} 